The Level of Literacy Obsolescence in the Thesis of Master Study Program of Management at Muhammadiyah University Hospital, Yogyakarta

\section{Tingkat Keusangan Literatur Pada Tesis Prodi Magister Manajemen Rumah Sakit Universitas Muhammadiyah Yogyakarta}

\section{Arda Putri Winata dan Yuliana Ramawati}

Universitas Muhammadiyah Yogyakarta
Paper Type:

Research Paper

Submitted 25 March 2019 Accepted 30 April 2019

Online 30 September 2019

* Correspondence: Arda Putri Winata

E-mail:

Background of the study: The level of obsolescence of references used in the thesis of the Master study program of Hospital Management.

Purpose: The purpose of this study is to determine the level of obsolescence of the references used in the thesis of the Master study program of Hospital Management.

Method: This study uses a quantitative descriptive method with a sample in the form of a student thesis Program Study of the Management at Muhammadiyah University Hospital Yogyakarta in 2017 totaling 48 pieces of theses.

Findings: Data is displayed in a table with a description. Obtained the results of $\mathrm{Md}=2009$. Thus, the citation below the year 2009 with a total of $857(43.5 \%)$ citation was declared obsolete, while the citation above the year 2009 with a total of 1112 (56.5\%) was declared valid.

Conclusion: From this explanation, it can be concluded that the level of obsolescence of literature in the thesis of the master's study program in the management of Muhammadiyah UniversityYogyakarta is obtained from $\mathrm{Md}=$ 2009. Then, the citation below in 2009 with a total of 857 (43.5\%) citation was declared obsolete, while the citation above 2009 with a total of $1112(56.5 \%)$ declared valid.

Keywords: Obsolescence, Literature, Thesis, UMY 


\section{Abstrak}

Latar Belakang Masalah: Tingkat keusangan rujukan yang digunakan dalam tesis program studi Magister Manajemen Rumah Sakit (MMR).

Tujuan: Tujuan dari penelitian ini adalah untuk mengetahui tingkat keusangan rujukan yang digunakan dalam tesis program studi Magister Manajemen Rumah Sakit (MMR).

Metode: Penelitian ini menggunakan metode deskriptif kuantitatif dengan sampel berupa tesis mahasiswa Program Studi Magister Manajemen Rumah Sakit Universitas Muhammadiyah Yogyakarta pada tahun 2017 sebanyak 48 buah tesis. Hasil: Data ditampilkan dalam tabel dengan deskripsi. Diperoleh hasil $\mathrm{Md}=$ 2009. Maka, sitiran di bawah tahun 2009 dengan jumlah 857 (43,5\%) sitiran dinyatakan usang, sedangkan sitiran di atas tahun 2009 dengan jumlah 1112 $(56,5 \%)$ dinyatakan valid.

Kesimpulan: Dari pemaparan tersebut dapat disimpulkan bahwa tingkat keusangan literatur pada tesis prodi magister manajemen rumah sakit universitas muhammadiyah Yogyakarta ialah diperoleh hasil $\mathrm{Md}=2009$. Maka, sitiran di bawah tahun 2009 dengan jumlah 857 (43,5\%) sitiran dinyatakan usang, sedangkan sitiran di atas tahun 2009 dengan jumlah $1112(56,5 \%)$ dinyatakan valid.

Kata Kunci: Keusangan, Literatur, Tesis, UMY 


\section{Pendahuluan}

Setiap mahasiswa pada jenjang S1, S2, maupun S3 diwajibkan untuk membuat karya ilmiah akhir sebagai syarat untuk menyelesaikan pendidikannya. Karangan ilmiah sendiri ialah pokok pikiran ilmu pengetahuan yang menyuguhkan suatu fakta dan ditulis sesuai dengan metodologi penulisan yang efektif serta efisien (Arifin, 2008). S1 harus menyelesaikan skripsi, S2 menyelesaikan Tesis, dan S3 menyelesaikan disertasi. Menyelesaikan tugas akhir tentu memiliki beban sesuai dengan jenjang pendidikannya. Untuk studi lanjut S2 dan S3, tugas akhir merupakan hasil penelitian yang mendalam. Selain menentukan topik penelitian juga membutuhkan sumber rujukan yang lengkap dan akurat. Penulisan tesis dan disertasi sangat dianjurkan untuk mengunakan jurnal ilmiah, baik nasional maupun internasional yang sesuai dengan topik penelitian. Sumber rujukan yang disitasi dalam sebuah penelitian harus mencantumkan daftar pustaka atau bibliografi. Daftar pustaka berfungsi untuk memberikan deskripsi buku atau jurnal yang dijadikan rujukan secara lengkap dengan tujuan agar para pembaca yang ingin mengetahui lebih lanjut mengenai rujukan tersebut dapat mencarinya dalam daftar pustaka, oleh karena itu kegiatan mensitasi dokumen merupakan bagian penting dari kegiatan penulisan karya ilmiah.

\section{Metode Penelitian}

Penelitian ini menggunakan metode deskriptif kuantitatif dengan sampel berupa tesis mahasiswa Program Studi Magister Manajemen Rumah Sakit Universitas Muhammadiyah Yogyakarta pada tahun 2017 sebanyak 48 buah tesis. Yusuf (2014) mengatakan bahwa penelitian deskriptif kuantitatif ialah penelitian yang mempunyai tujuan untuk mendeskripsikan secara faktual, sistematis, serta akurat tentang sifat atau fakta-fakta yang terdapat di dalam populasi tertentu atau penggambaran secara detail. Metode pengumpulan data menggunakan metode dokumentasi. Metode dokumentasi merupakan sebuah catatan peristiwa yang telah berlalu, baik dalam bentuk gambar, tulisan, ataupun karya seseorang (Sugiyono, 2013). Peneliti mengumpulkan seluruh tesis Prodi MMR yang berjumlah 48 buah kemudian mengkelompokkan rujukan-rujukan yang terdapat dalam tesis tersebut sesuai dengan tahunnya.

\section{Hasil}

Bahan pustaka atau yang biasa disebut dengan literatur yang disitir dalam sebuah karya tulis ilmiah harus tercantum ke dalam bibliografi ataupun daftar pustaka (Hayati, 2016). Analisis sitiran atau kajian sitiran merupakan studi mengenai kutipan dalam sebuah teks, jurnal, ataupun sumber referensi lainnya (Hasugian, 2005). Kajian mengenai sitiran telah banyak dilakukan di Indonesia, beberapa diantaranya kajian yang dilakukan oleh Atiqah Ainur Rahma (2017) dengan judul Pemanfaatan Jurnal Psikologi Dalam Penyusunan Tesis Mahasiswa Psikologi UGM tahun 2012. Hasil penelitian tersebut menunjukkan bahwa Pemanfaatan jurnal psikologi terbitan luar negeri yang dilanggan lebih tingi $(12,72 \%)$ daripada pemanfaatan jurnal psikologi terbitan dalam negeri $(2,44 \%)$, pemanfaatan jurnal terbitan luar negeri lebih tinggi daripada jurnal terbitan dalam negeri. Kemutakhiran jurnal yang digunakan sebagai referensi tesis Fakultas Psikologi UGM tahun 2012 termasuk dalam kategori mutakhir sebanyak 67,76\%, sedangkan kategori tidak mutakhir sebanyak 31,81\%.

Kajian sitiran ialah sebuah teknik bibliometrik untuk meneliti suatu karya dalam kutipan yang dipublikasikan demi mendapatkan sebuah pola yang sesuai (Johnson, 2009). Manfaat dari kajian sitiran sendiri ialah sebagai bentuk dalam mengetahui perkembangan serta pertumbuhan literatur tertentu. Kajian sitiran dapat digunakan sebagai alat evaluasi koleksi perpustakaan sebagaimana kajian yang dilakukan oleh Nurul Hayati (2016) yang berjudul Analisis Sitiran sebagai Alat Evaluasi Koleksi Perpustakaan, hasil dari kajian tersebut adalah bahwa, "Analisis sitiran merupakan pendekatan yang terpusat pada bahan pustaka dan difokuskan pada bahan pustaka dalam sebuah koleksi. Melalui analisis sitiran ini, dapat diketahui pertumbuhan dan perkembangan ilmu pengetahuan dalam subjek tertentu. Dalam analisis sitiran juga dapat digambarkan adanya hubungan antara sebagian atau seluruh dokumen yang disitir dengan dokumen yang menyitir. Dalam hal ini dapat dihitung seberapa banyak karya tulis yang disitir oleh para penulis ilmiah. Bagi perpustakaan, hasil kajian analisis sitiran ini dapat dijadikan

To cite this document:

Winata, A. P., \& Ramawati Y. (2018). Tingkat Keusangan Literatur Pada Tesis Prodi Magister Manajemen Rumah

Sakit Universitas Muhammadiyah Yogyakarta. Record and Library Journal, 4(2), 120-126.

Open access under Creative Commons Attribution-Non Commercial-Share A like 4.0 International Licence

(CC-BY-SA) @ (9) (9) 
Arda Putri Winata| Tingkat Keusangan Literatur Pada Tesis Prodi Magister Manajemen Rumah Sakit Universitas Muhammadiyah Yogyakarta

sebagai bahan pertimbangan dalam membuat kebijakan pengembangan koleksinya."

Analisis sitiran juga dapat memberikan gambaran tentang produktivitas seorang pustakawan sebagaimana kajian yang dilakukan oleh Syarianah (2016) yang berjudul Produktivitas Peneliti Pusat Penelitian Dan Pengembangan Perikanan Budidaya: Suatu Kajian Pada Jurnal Riset Akuakultur. Dari hasil penelitian tersebut dapat diperoleh hasil bahwa "Penulis pertama yang memberi kontribusi lebih dari satu artikel terbanyak berasal dari BPPBAP Maros yaitu 17 (30.36\%), BBPPBL Gondol 12 (21,43\%), BPPBAT Bogor 10 (17.87\%), P4B Jakarta 7 (15.63\%), dan BPPBIH Depok 5 (8.93\%). Artikel dengan kolaborasi tiga penulis merupakan yang terbanyak, yaitu 82 artikel (36.44\%), disusul kolaborasi dua penulis yaitu 53 artikel $(23.56 \%)$ kemudian kolaborasi empat sebanyak 51 artikel (22.67\%). Kolaborasi lima penulis sebanyak 20 artikel (8.89\%), kolaborasi enam penulis. 4 artikel (1.78\%), kolaborasi tujuh, delapan dan sembilan masing-masing 1 artikel (0.44\%).”

Mengingat analisis sitiran penting dilakukan maka perlu diketahui bahwa yang dimaksud sitiran menurut Lasa Hs (2009) merupakan "Rujukan pada bagian dari teks yang memperkenalkan dokumen yang diperoleh." Analisis sitiran adalah suatu teknik bibliografi dengan menyitir rujukan pada terbitan yang di telaah untuk mendapatkan suatu pola komunikasi ilmiah antar disiplin ilmu. Menurut Sutardji (2003) karakteristik atau sifat literatur yang akan disitir oleh penulis seperti halnya tahun terbit, jenis, usia, pengantar bahasa, serta peringkat majalah yang disitir. Analisis sitiran bisa dipakai dalam meneliti keterpakaian semua jenis koleksi yang akan disitir, ketersediaan koleksi, mengukur besarnya pengaruh (artikel, jurnal, instansi atau lembaga), kemutakhiran koleksi yang disitir, serta pola sitasi untuk karakteristik pemakai tertentu (Safitri, 2016). Sedangkan menurut Hartinah (2002) analisis sitiran ialah penyelidikan sebuah data sitiran yang berasal dari dokumen, baik dokumen yang menyitir ataupun dokumen yang disitir. Metode tersebut bisa dipakai dalam menyelidiki subjek, pengarang, serta sumber dokumen meliputi tahun terbit, dan nama jurnal.

Analisis dengan menggunakan metode sitiran sangatlah mudah, hanya memerlukan sebuah kecermatan yang tinggi serta ketekunan. Analisis sitiran menghasilkan sebuah presentase data koleksi, baik koleksi yang dirujuk ataupun jenis koleksi yang paling banyak digunakan (Mariati, 2016). Beberapa Kendala dalam analisis sitiran menurut Mariati (2016) antara lain: Pertama, terdapat kepengarangan yang rangkap. Daftar artikel sitiran di indeks sitiran hanya terdapat nama pengarang yang pertama saja. Kedua, Sitiran yang bersifat karya individu atau pribadi. Jika sebuah sitiran pribadi dihapuskan dari hitungan sitiran, maka hal tersebut mudah dilakukan kepada sebuah karya yang dibuat oleh pengarang tunggal. Ketiga, Homograf. Jika penulis mempunyai nama serta inisial yang mirip, maka sebagai pembedanya ialah badan afiliasi penulis tersebut. Keempat, sinonim. Sitiran tersebut akan menyebar dalam bentuk standar untuk nama pengarang beserta jumlah inisial seperti, J Licklider, Licklider, JKR, JC Licklider.

Penelitian ini membahas mengenai keusangan literature (obsolescence) yang digunakan dalam tugas akhir Magister Manajemen Rumah Sakit Universitas Muhammadiyah Yogyakarta pada tahun 2017 sebanyak 48 buah tesis. Keusangan literatur tersebut berkaitan dengan suatu informasi yang terdapat di dalam dokumen tersebut. Keusangan dokumen bersifat praktis, maksudnya ialah apabila terdapat suatu dokumen yang sudah usang maka sebagian besar dokumen tersebut akan disiangi (weeding) maupun di tempatkan dalam gudang. Keusangan sebuah informasi mempunyai arti bahwa informasi yang terdapat di dalam dokumen sudah tidak terpakai atau jarang digunakan dalam penelitian baru, dengan adanya hal tersebut maka pemanfaatan dan penggunaan informasinya telah mengalami penurunan serta pada akhirnya dokumen tersebut sudah tidak dimanfaatkan lagi.

Usia half-life atau yang biasa disebut dengan paro hidup merupakan literatur yang dilihat berdasarkan jenis serta usia yang dirujuk oleh artikelnya. Walaupun literatur tergolong usia paro hidup atau usang, namun bila literatur tersebut mempunyai informasi yang sangat relevan mengenai topik bahasan yang diperlukan oleh pengguna informasi maka literatur tersebut bisa juga dipakai dalam rujukan penelitian yang baru. Usia paro hidup literatur dalam disiplin ilmu, memperlihatkan kesigapan pertumbuhan suatu literatur dalam bidang tersebut. Rumus untuk mencari usia paro hidup sebuah literatur sebagaimana dikemukakan Azwar (2004).

To cite this document:

Winata, A. P., \& Ramawati Y. (2018). Tingkat Keusangan Literatur Pada Tesis Prodi Magister Manajemen Rumah

Sakit Universitas Muhammadiyah Yogyakarta. Record and Library Journal, 4(2), 120-126.

Open access under Creative Commons Attribution-Non Commercial-Share A like 4.0 International Licence

(CC-BY-SA) @ () (2) 
Arda Putri Winata| Tingkat Keusangan Literatur Pada Tesis Prodi Magister Manajemen Rumah Sakit Universitas Muhammadiyah Yogyakarta

$$
\mathrm{Md}=\mathrm{Lmd}+\frac{(\text { Fmd }) .}{(\mathrm{Jmd})} \mathrm{i}
$$

Untuk menghitung tingkat keusangan sebuah literatur, penulis mengurutkan tahun terbit rujukan yang dipakai mahasiswa dalam penulisan tesis Program Studi Magister Manajemen Rumah Sakit UMY Yogyakarta, tesis yang terdiri dari 48 buah yang digunakan sebagai sampel dalam penelitian ini. Penulis membagi tahun terbit rujukan dengan menggunakan interval 10, dari tahun paling tua sampai tahun yang paling baru. Setelah itu, diambil median yang akan membagi rujukan yang sudah diurutkan tersebut dengan prosentase kumulatif.

Menurut Sulistyo Basuki dalam Mariati, (2016) semakin baru usia paro hidup suatu dokumen memperlihatkan sebuah perkembangan disiplin ilmu yang begitu cepat. Sehingga keusangan sebuah dokumen akan berbeda, seperti halnya usia paro hidup literatur bidang Biomedis hanya 3,0 tahun, ilmu Hukum 12,9 tahun, Kimia 8,1 tahun, Fisika 4,6 tahun, Kedokteran 6,8 tahun, Botani 10,0 tahun, serta Geografi 16, 0 tahun dan sebagainya.

Usia paro hidup atau dalam bahasa inggris disebut half-life yang mempunyai arti setengah waktu dari semua literatur disiplin ilmu yang dipakai secara berkala sejak diterbitkan pertama kali. Kajian usia paro hidup berguna untuk mempertimbangkan sebuah literatur digunakan dalam jangka waktu tertentu, efisiensi pengelolaan koleksi perpustakaan, serta indikator kemutakhiran suatu bidang ilmu. Obsolescence atau keusangan literatur ialah sebuah konsep yang nisbi atau relatif, karena terdapat literatur baru terbit tapi sudah jarang dipakai lagi, namun sebaliknya terdapat literatur terbitan lama tapi masih tetap dipakai oleh orang banyak.

Setelah mengumpulkan sebuah data, kemudian data diolah menjadi bentuk yang sederhana. Seluruh tesis (48 tesis) di inputkan kedalam tabel. Jumlah sitiran dari keseluruhan tesis adalah 1969 sitiran dari 48 buah tesis. Tahun sitiran tertua (terlama) yakni tahun 1955, dengan tahun sitiran termuda (terbaru) yakni tahun 2017, dan tanpa tahun 1 sitiran. Berikut ini data sitiran Tesis MMR UMY Tahun 2017 dengan interval 5 tahun.

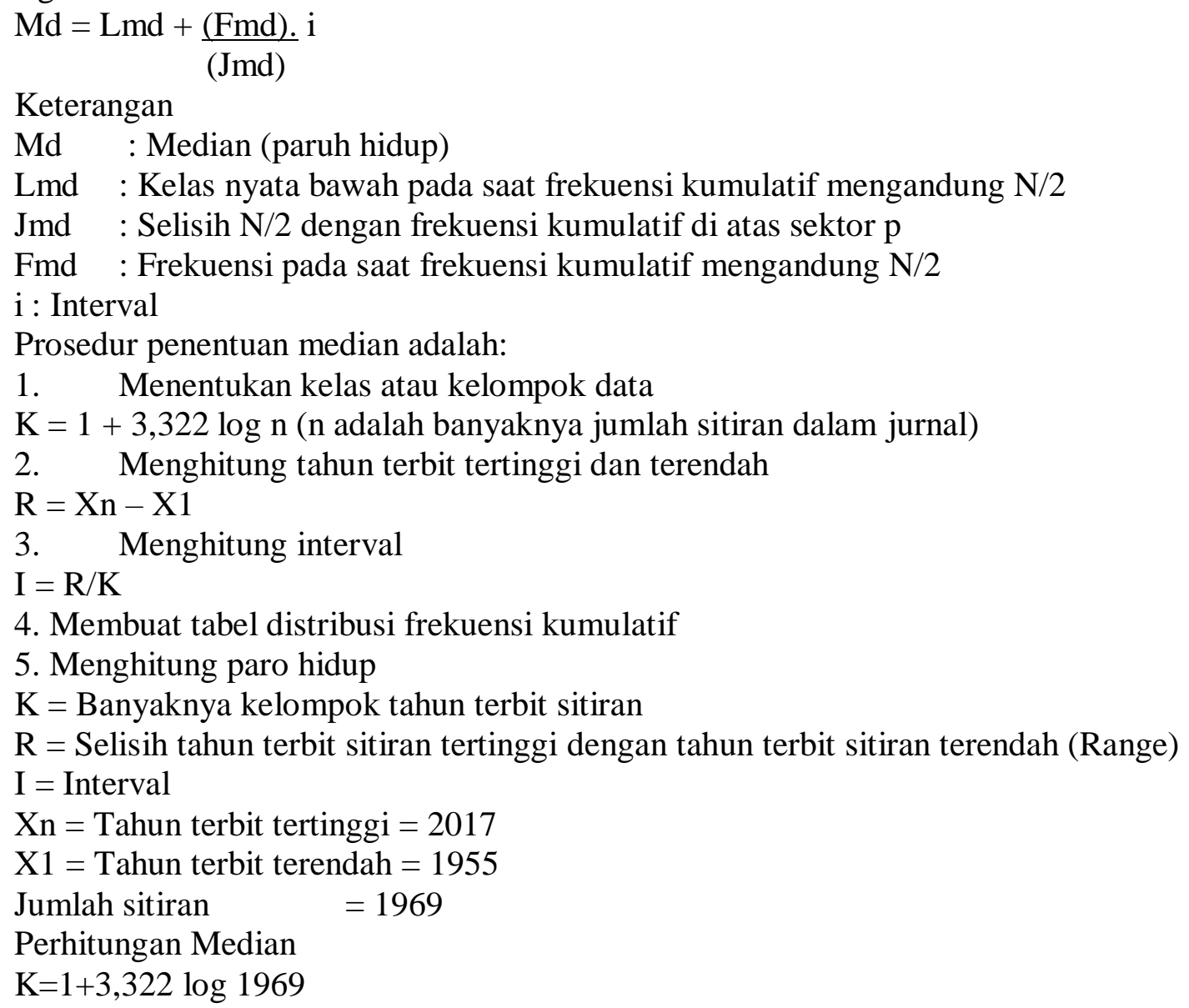

To cite this document:

Winata, A. P., \& Ramawati Y. (2018). Tingkat Keusangan Literatur Pada Tesis Prodi Magister Manajemen Rumah Sakit Universitas Muhammadiyah Yogyakarta. Record and Library Journal, 4(2), 120-126. 


$$
\begin{aligned}
& \quad=1+3,322.3 .294 \\
& =1+10,94 \\
& =11,94 \\
& \text { Penentuan range } \\
& \mathrm{R}=\mathrm{Xn}-\mathrm{X} 1=2017-1955=62 \\
& \text { Penentuan Interval } \\
& \mathrm{I}=\mathrm{R} / \mathrm{K}=62 / 11,94=5,193=5
\end{aligned}
$$

Tabel 1. Literatur dalam interval 5 tahun

\begin{tabular}{cccc}
\hline No & Tahun & $\begin{array}{c}\text { Frekuensi } \\
\text { Sitiran }\end{array}$ & $\begin{array}{c}\text { Frekuensi } \\
\text { Kumulatif }\end{array}$ \\
\hline 1 & $1955-1960$ & 2 & 2 \\
2 & $1961-1966$ & 1 & 3 \\
3 & $1967-1972$ & 2 & 5 \\
4 & $1973-1978$ & 3 & 8 \\
5 & $1979-1984$ & 9 & 17 \\
6 & $1985-1990$ & 21 & 38 \\
7 & $1991-1996$ & 55 & 93 \\
8 & $1997-2002$ & 173 & 266 \\
9 & $2003-2008$ & 576 & 842 \\
10 & $2009-2014$ & 868 & 1710 \\
11 & $2015-2020$ & 244 & 1954 \\
12 & No Years & 15 & \\
& JUMLAH & 1969 & 1969 \\
\hline
\end{tabular}

\section{Simpulan}

Dari pemaparan tersebut dapat disimpulkan bahwa tingkat keusangan literatur pada tesis prodi magister manajemen rumah sakit universitas muhammadiyah yogyakarta ialah diperoleh hasil Md = 2009. Maka, sitiran di bawah tahun 2009 dengan jumlah 857 (43,5\%) sitiran dinyatakan usang, sedangkan sitiran di atas tahun 2009 dengan jumlah $1112(56,5 \%)$ dinyatakan valid.

\section{Ucapan Terima Kasih}

Penulis mengucapkan terima kasih kepada pihak Universitas Muhammadiyah Yogyakrta yang telah memberikan dukungan kepada penulis dalam melakukan penelitian.

\section{Referensi}

Arifin, Z. (2008). Metodelogi Penelitan Pendidikan. Surabaya: Lentera Cendikia.

Rahma, A. (2017). Pemanfaatan Jurnal Psikologi Dalam Penyusunan Tesis Mahasiswa Psikologi UGM Tahun 2012. Berkala Ilmu Perpustakaan Dan Informasi, 13(1), 12-24.

Azwar, S. (2004). Metode Penelitian. Yogyakarta: Pustaka Pelajar.

Hartinah, S. (2002). Analisis Sitiran (Citation Analysis).Dalam Kumpulan makalah Kursus B i b l i o m e t r i k a. Depok: Masyarakat Informaetrika Indonesia.

Hasugian, J. (2005). Analisis sitiran terhadap disertasi Program Doktor (S-3) Ilmu Kedokteran Sekolah Pascasarjana Universitas Sumatera Utara. Jurnal Pustaha: Program Studi Perpustakaan dan Informasi, 1(2), 1-11.

Hayati, N. (2016). Analisis Sitiran sebagai Alat Evaluasi Koleksi Perpustakaan. Record And Library Journal, 2(1), 01-15.

Johnson, P. (2009). Fundamentals of collection development and management. Chicago: American Library Association.

To cite this document:

Winata, A. P., \& Ramawati Y. (2018). Tingkat Keusangan Literatur Pada Tesis Prodi Magister Manajemen Rumah

Sakit Universitas Muhammadiyah Yogyakarta. Record and Library Journal, 4(2), 120-126.

Open access under Creative Commons Attribution-Non Commercial-Share A like 4.0 International Licence

(CC-BY-SA) @( () (2) 
Arda Putri Winata| Tingkat Keusangan Literatur Pada Tesis Prodi Magister Manajemen Rumah Sakit Universitas Muhammadiyah Yogyakarta

Lasa, H. s. (2009). Kamus Kepustakawanan Indonesia. Yogyakarta: Book Publisher.

Mariati. (2016). Evaluasi Literatur Skripsi Mahasiswa Prodi Kimia Angkatan 2009 Terhadap Ketersediaan Literature di Perpustakaan Fakultas Keguruan dan Ilmu Pendidikan Unsyiah Banda Aceh (Pendekatan Analisis Sitiran). Libria, 8(2), 265-281.

Safitri, R. S. (2016). Analisis Sitiran Terhadap Tesis Mahasiswa Magister Sains Psikologi Dan Ketersedian Koleksi Perpustakaan Fakultas Psikologi Uin Syarif Hidayatullah Jakarta. Jakarta: Fakultas Psikologi Uin Syarif Hidayatullah.

Sugiyono. (2013). Metodelogi Penelitian Kuantitatif, Kualitatif Dan R\&D. Bandung: Alfabeta.

Sutardji. (2003). Pola Sitiran Dan Pola Kepengarangan Pada Jurnal Penelitian Tanaman Pangan. Jurnal Perpustakaan Pertanian, 12(1), 1-9.

Syarianah. (2016). Produktivitas Peneliti Pusat Penelitian Dan Pengembangan Perikanan Budidaya : Suatu Kajian Pada Jurnal Riset Akuakultur. Jurnal Pari, 2(1), 16-24.

Yusuf, M. (2014). Metode Penelitian: Kuantitatif, Kualitatif, Dan Penelitian Gabungan. Jakarta: Kencana. 